\title{
Investigation of the early intestinal microflora in premature infants with/without necrotizing enterocolitis using two different methods
}

\author{
Birgitte Smith', Susan Bodé2,4, Thomas H. Skov ${ }^{3}$, Hengameh Mirsepasi', Gorm Greisen ${ }^{2}$ and Karen A. Krogfelt ${ }^{1}$
}

INTRODUCTION: The pathophysiology of necrotizing enterocolitis (NEC) is multifactorial, and gastrointestinal bacteria are thought to play an important role. In this study, the role of microflora in the gastrointestinal tract of neonates with NEC was assessed by comparing cases with controls.

RESULTS: Of the 163 neonates, 21 developed NEC. The risk of NEC decreased by $8 \%$ with each additional day of gestational age.

DISCUSSION: Typically, very few bacterial species could be cultured from the fecal specimens obtained. Gram-positive $\left(\mathrm{G}^{+}\right)$bacteria dominated the samples in the NEC group, whereas in the control group mixed flora of $\mathrm{G}^{+}$and Gram-negative $\left(\mathrm{G}^{-}\right)$bacteria were isolated. Surprisingly, molecular analysis using PCR-DGGE profiles did not confirm these differences. Our data suggest that $\mathrm{G}^{+}$bacteria in the intestine may play a role in the development of NEC in premature infants.

METHODS: One hundred and sixty three neonates born at $<30$ weeks of gestation were enrolled. Fecal samples taken during the first month of life were subjected to culture and PCRdenaturing gradient gel electrophoresis (PCR-DGGE). A total of 482 fecal samples were examined.

N ecrotizing enterocolitis (NEC) is an acute inflammatory disease that affects the intestinal tracts of neonates (1); it is one of the most frequent gastrointestinal emergencies in premature neonates (2). The pathophysiology of NEC is multifactorial. A healthy intestine relies on perfect balance and interactions between the host epithelium, immune cells, and the microflora present. It is known that any abnormality in the ecosystem of the gastrointestinal tract may result in a pathological process potentially leading to NEC (3). It is suspected that abnormal colonization of the gastrointestinal tract or an unfavorable balance between commensal and pathogenic bacteria is part of the pathogenesis of NEC (4-6). It has been suggested that the ability of microflora to invade the epithelium and ferment unabsorbed nutrients (7), and the colonization by various bacterial pathogens in a sufficiently vulnerable host (8) could promote the development of NEC. Bacterial colonization of the neonatal gut is influenced by factors such as gestational age, feeding, medication, and diverse environmental flora (9). Premature neonates are exposed to the environmental flora present in the neonatal intensive care unit. Furthermore, they are often treated with broad-spectrum antibiotics and do not tolerate enteral feeds. It is likely that these circumstances promote bacterial colonization leading to NEC. The microflora in the premature intestine are characterized by decreased biodiversity (10) and imbalance, with overgrowth of potential pathogens. In this situation, mucosal lesions could give bacteria systemic access to the intestinal wall and contribute to the development of NEC.

Currently, there is a lack of detailed knowledge relating to the early bacterial colonization of the intestinal tracts of premature infants, and to the mechanisms underlying the establishment of intestinal microflora. The aim of this project was to determine the importance of bacterial flora in the development of NEC in premature infants. The bacterial flora were analyzed by fecal culture and DNA analysis in a large cohort of preterm infants during the first 4 weeks of life. Furthermore, the microflora from infants who developed NEC were compared with the flora of preterm infants who did not.

\section{RESULTS}

A total of 192 premature infants, born at $<30$ weeks of gestation, were found to be eligible for this study. The parents of 165 of these infants were requested to consent to the enrolling of the infants in the study; in two cases, consent was declined. The premature neonates included in the study were born between 23 and 29 weeks of gestation. Of the 163 infants enrolled, 21 developed NEC during their hospital stay. Diagnosis was according to Bell's criteria (14). The incidence of NEC had a strong inverse relationship with gestational age; the likelihood of developing NEC decreased by $8 \%$ (range $3.4,13.2$ ) for each additional day of gestational age. The characteristics of the infants are presented in Table 1.

A total of 482 fecal samples were collected from the infants and subjected to culture and molecular methods for detection of bacteria. Between 1 and 3 fecal samples were collected from each of the infants during the first months of life, ranging from day 0 to day 96 after birth. 
Detection of Fecal Bacteria in Culture

All fecal samples were subjected to culture, and all bacterial species isolated were identified by classical microbiological methods. The species of bacteria isolated are shown in Table 2.

In the fecal samples from the neonates, very few bacterial species were detected, the predominant species being Staphylococcusspp., Enterococcus spp., Klebsiella spp., Escherichia coli, Clostridium spp., and Enterobacter spp., Yeast, Lactobacillus spp., and Bifidobacterium spp., were seldom, if ever, found.

On an assessment of the bacterial diversity of the fecal flora it was seen that neonates from whose feces fewer than three species of bacteria were grown in culture tended to be at increased risk of developing NEC (odds ratio 4.6 (95\% confidence interval $0.98 ; 21.8)$ ) (Table 2).

Comparisons of the fecal microflora in the premature neonates showed that, overall, the intestines of those who did not develop NEC were colonized by a diversity of flora comprising both Gram-negative $\left(\mathrm{G}^{-}\right)$and Gram-positive $\left(\mathrm{G}^{+}\right)$bacterial species (Table 2). In contrast, the premature neonates who developed NEC were generally those who were colonized predominantly by flora consisting of $\mathrm{G}^{+}$bacteria.

Colonization by Staphylococcus spp. was significantly more prevalent in neonates who went on to develop NEC than in the control neonates who developed NEC $(P=0.004)$. It was striking that, $\sim 1$ month after birth (sample 3 ) the neonates who developed NEC continued to differ significantly from the

Table 1. Data on the premature population

\begin{tabular}{lccc}
\hline & Controls $(n=142)$ & NEC $(n=21)$ & $P$ value \\
\hline $\begin{array}{l}\text { Mean gestational age } \\
\text { (min., max. days) }\end{array}$ & $191(161-209)$ & $183(166-201)$ & $<0.001$ \\
Sex ratio: male/female & $66 / 76$ & $11 / 10$ & NS \\
Deceased & $3 \%$ & $29 \%$ & $<0.001$ \\
\hline
\end{tabular}

Controls did not develop NEC.

NEC, necrotizing enterocolitis; NS, not significant. control infants in respect to colonization by Staphylococcus spp. $(P<0.001)$. Certain $\mathrm{G}^{-}$bacterial species that are typically considered to be nosocomial pathogens were detected in the control infants. For instance, Klebsiella spp. were detected more frequently in control neonates than in the NEC neonates during the first month of life (for sample 1: $P=0.03$; for sample 3: $P=0.003$ (Table 2)).

\section{Determination of Bacterial Diversity in Fecal Samples Using $16 \mathrm{~S}$ rDNA PCR-DGGE}

DNA was extracted from fecal samples, and 16S rDNA was amplified. The $16 \mathrm{~S}$ rDNA denaturing gradient gel electrophoresis (DGGE) profile for each infant was unique. Bacterial diversity was assessed from the band richness of each sample. There were no differences in band richness between the profiles of neonates who developed NEC and those of the controls who did not develop NEC. This held true whether all the samples were considered together or sample 1, sample 2, or sample 3 were considered pairwise (Table 3 ). Principal component analysis (PCA) was carried out, considering each DGGE profile to be the unique "fingerprint" of a particular neonate. PCA is a powerful multivariate technique that can extract patterns (i.e., certain combinations of bands/bacteria) related to children diagnosed with NEC and control children, provided these patterns are present in data. Using this approach it would be possible to evaluate whether certain combinations of bands are present in neonates with NEC but not in control neonates.

Inspection of the score plots of the primary principal components showed no discriminating feature associated with any particular band position (Figure 1), indicating that no specific bacterium or combination of bacteria were present in one patient group and absent in the other. This was validated using other multivariate techniques, and no patterns relating specifically to neonates with NEC could be found. The only apparent difference between the two patient groups was the number of bands, i.e., band richness. However, the mean band richness of

Table 2. Bacterial species detected in feces from premature neonates

\begin{tabular}{|c|c|c|c|c|c|c|}
\hline \multirow[b]{3}{*}{ Sample } & \multicolumn{3}{|c|}{ Control } & \multicolumn{3}{|c|}{ NEC } \\
\hline & 1 & 2 & 3 & 1 & 2 & 3 \\
\hline & $(n=128)$ & $(n=128)$ & $(n=124)$ & $(n=15)$ & $(n=15)$ & $(n=15)$ \\
\hline Staphylococcus spp.* & $64 \%(82)$ & $51 \%(65)$ & $15 \%(19)$ & $80 \%(12)^{* *}$ & $67 \%(10)$ & $67 \%(10)^{* * * *}$ \\
\hline Enterococcus spp. & $28 \%(32)$ & $51 \%(65)$ & $60 \%(75)$ & $7 \%(1)$ & $40 \%(6)$ & $67 \%(10)$ \\
\hline Escherichia coli & $7 \%(9)$ & $9 \%(11)$ & $22 \%(27)$ & $7 \%(1)$ & 0 & $20 \%(3)$ \\
\hline Klebsiella spp. ${ }^{\dagger}$ & $10 \%(13)$ & $25 \%(32)$ & $48 \%(59) \ddagger$ & $13 \%(2)$ & $7 \%(2)$ & $7 \%(2)$ \\
\hline Pseudomonas spp. & $3 \%(4)$ & $2 \%(2)$ & $2 \%(2)$ & $7 \%(1)$ & 0 & $7 \%(1)$ \\
\hline Enterobacter spp. & $6 \%(8)$ & $13 \%(16)$ & $10 \%(12)$ & $7 \%(1)$ & 0 & $7 \%(1)$ \\
\hline
\end{tabular}

Staphylococcus spp: ${ }^{*} P=0.004,{ }^{* *} P=0.048,{ }^{* * *} P<0.001$.

Klebsiella spp: $\uparrow P=0.03, \neq P=0.003$.

$n$, number of samples; NEC, necrotizing enterocolitis. 
Table 3. Statistical analysis of culturing and PCR-DGGE from fecal samples

\begin{tabular}{|c|c|c|c|}
\hline & NEC & Control & $P$ \\
\hline \multirow[t]{3}{*}{$\begin{array}{l}\text { Explanation of } \\
\text { numbers }\end{array}$} & Mean & Mean & $P$ value \\
\hline & Median (min;max) & Median (min;max) & \\
\hline & $\begin{array}{c}\text { (number of } \\
\text { observations) }\end{array}$ & $\begin{array}{c}\text { (number of } \\
\text { observations) }\end{array}$ & \\
\hline \multirow[t]{3}{*}{ DGGE } & 11.2 & 10.3 & 0.24 \\
\hline & $11(0 ; 25)$ & $10(0 ; 26)$ & \\
\hline & $(n=47)$ & $(n=423)$ & \\
\hline \multirow[t]{3}{*}{ Sample 1} & 10.9 & 10.0 & 0.72 \\
\hline & $8.5(2 ; 25)$ & $9(1 ; 23)$ & \\
\hline & $(n=14)$ & $(n=138)$ & \\
\hline \multirow[t]{3}{*}{ Sample 2} & 13.6 & 9.8 & 0.0059 \\
\hline & $13(7 ; 24)$ & $9(0 ; 24)$ & \\
\hline & $(n=16)$ & $(n=144)$ & \\
\hline \multirow[t]{3}{*}{ Sample 3} & 9.2 & 11.0 & 0.19 \\
\hline & $9(0 ; 19)$ & $11(0 ; 26)$ & \\
\hline & $(n=17)$ & $(n=141)$ & \\
\hline \multicolumn{4}{|l|}{ Culture } \\
\hline \multirow[t]{3}{*}{ All samples } & 1.8 & 1.9 & 0.40 \\
\hline & $2(1 ; 4)$ & $2(1 ; 6)$ & \\
\hline & $(n=47)$ & $(n=423)$ & \\
\hline \multirow[t]{3}{*}{ Sample 1} & 1.8 & 1.7 & 0.68 \\
\hline & $2(1 ; 3)$ & $1(1 ; 5)$ & \\
\hline & $(n=14)$ & $(n=138)$ & \\
\hline \multirow[t]{3}{*}{ Sample 2} & 1.5 & 1.9 & 0.05 \\
\hline & $1(1 ; 3)$ & $2(1 ; 4)$ & \\
\hline & $(n=16)$ & $(n=144)$ & \\
\hline \multirow[t]{3}{*}{ Sample 3} & 2 & 2.0 & 0.95 \\
\hline & $2(1 ; 4)$ & $2(1 ; 6)$ & \\
\hline & $(n=17)$ & $(n=141)$ & \\
\hline
\end{tabular}

DGGE, denaturing gradient gel electrophoresis; $N E C$, necrotizing enterocolitis.

Fecal samples were collected at postnatal age day 0-5 (sample 1), day 10 (sample 2), and day 30 postnatal (sample 3). PCR-DGGE: Mean: number of bands (band richness), Median: band richness ( $\mathrm{min}$. bands, $\mathrm{max}$. bands, $n$ : number of feces samples. Culture: Mean: mean number of bacterial species isolated, Median: median number of species (min., max.), $n$ : number of feces samples.

all three samples (1-3) from a neonate or of each sample individually calculated, was not significantly correlated to development of NEC (Table 3). Generally, all estimates were strengthened when analyzing the averages of all three samples.

Also, there was no difference in the overall number of species as determined by culture, either when all samples were compared together or when matched samples $(1,2$, or 3$)$ were compared between the two patient groups (NEC vs. controls) (Table 3).

Gender, gestation age, and feeding were treated as confounders in the analysis, and these had no association with the composition of the intestinal flora.

In the PCA analysis, we analyzed for antibiotic use as a confounder. However, because all the neonates received antibiotics at birth and/or subsequently for the treatment of sepsis, we could not register any influence of antibiotics on the colonization pattern.

\section{DISCUSSION}

The advantages of culturing bacteria are obvious, given that the bacteria in question are isolated and available for further characterization. One of the limitations in using conventional microbiological methods is that only cultivable organisms are detected. Other limitations of the culture include the selection of bacterial growth depending on the culture media used, the stress imposed by culture procedures, and the necessity for strictly anoxic conditions. A range of selective and nonselective media were used. Culture bias can be caused by overgrowth of numerous species on the selective and nonselective plates. Molecular techniques are independent of these limitations; however, these techniques require good DNA quality and appropriate extraction methods. DGGE is a commonly used technique in molecular biology. The method is powerful and can rapidly provide a distribution pattern as an indication of population diversity. Because DGGE analysis requires significant amounts of DNA for detection, a PCR must be performed before the analysis. Therefore, all the troublesome features of sampling, DNA extraction, PCR primer design, and PCR conditions should be considered when troubleshooting DGGE problems. Problems at each stage of this molecular technique can impact negatively on each stage downstream. The main problem in practice is the PCR. In general, PCRDGGE is found to be more sensitive than conventional culture, revealing numerous bands that indicate the presence of bacterial strains in addition to those that grow in culture.

Most studies on the composition of the gut microflora in neonates who go on to develop NEC have been carried out using traditional techniques of culture (11-14). Some studies have found an association between various bacterial species and NEC (15-20), whereas others did not observe any association between NEC and any specific bacterial species $(8,21)$.

By carrying out culture of the fecal samples, we showed that the neonates who developed NEC were colonized predominately by $\mathrm{G}^{+}$bacteria, whereas the control neonates were colonized by diverse bacterial flora comprising both $\mathrm{G}^{+}$and $\mathrm{G}^{-}$bacterial species. In contrast, we found no association between the composition of fecal bacteria and development of NEC when we used molecular methods of analysis. These results are consistent with the findings of Millar et al. (22), who were the first to describe microflora using $16 \mathrm{~S}$ rRNA gene PCR and DGGE in 32 premature neonates including 10 neonates with NEC. They found that, as compared with fecal samples from control neonates, samples from neonates who went on to develop NEC included many more kinds of bacteria that did not grow in culture. de la Cochetiere et al. (23), using the molecular technique of temperature gradient gel electrophoresis, detected a band corresponding to Clostridium perfringens in three cases of neonates with NEC but in none of the controls. In our study, no specific DNA bands were correlated with the development of NEC. Similarly, Mshvildadze et al. (20) found that the overall microbial profiles of samples from neonates with NEC were indistinguishable from those in control neonates. 

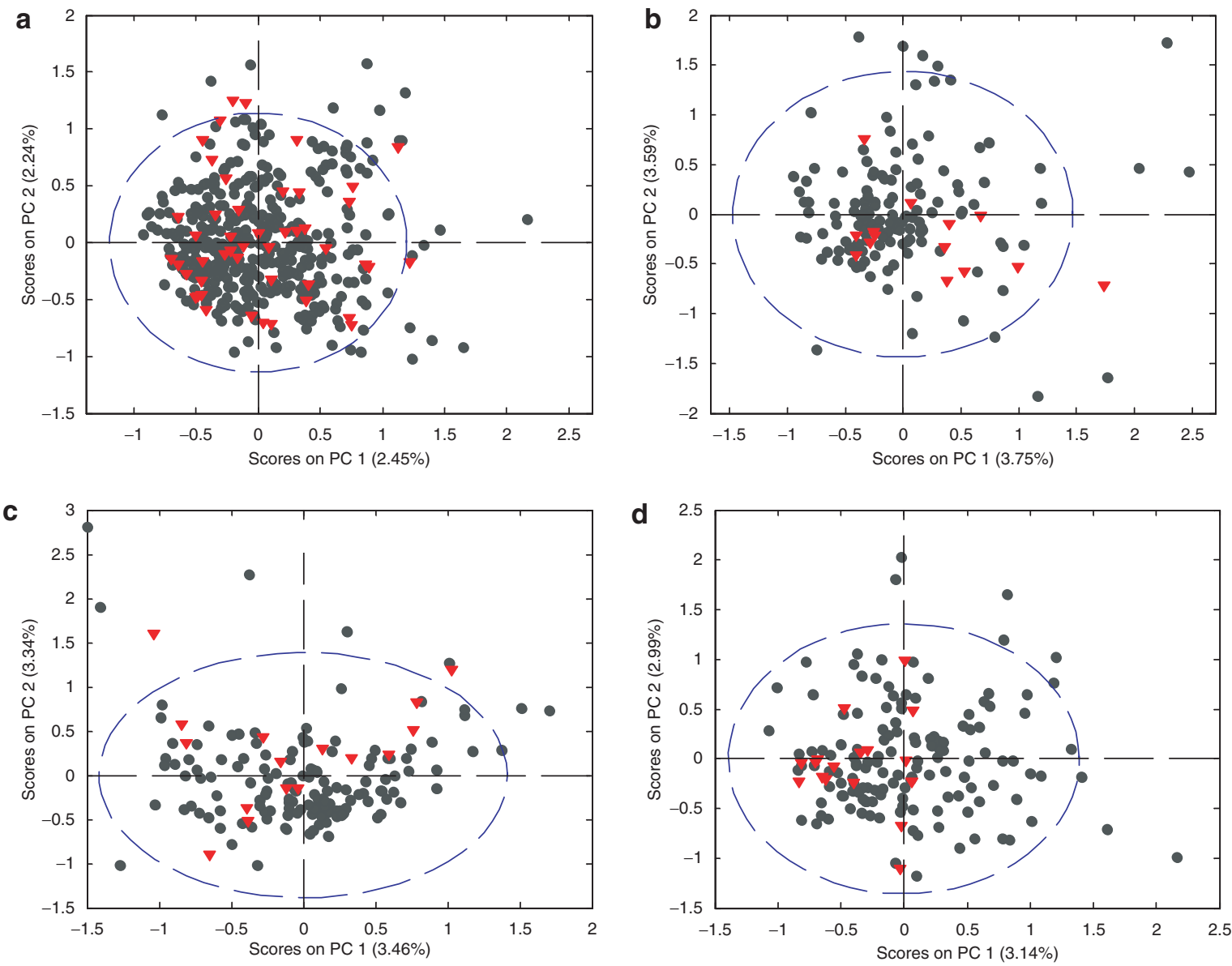

Figure 1. Principal component analysis (PCA) plot based on denaturing gradient gel electrophoresis band profiles. (a) Data from all samples obtained during the first month of life; (b) PCA plot of sample 1 from all the infants, taken during 0-5 days after birth; (c) PCA plot of sample 2 from all the infants, taken 10 days after birth; and (d) PCA plot of sample 3 from all the infants taken 30 days after birth. Black dots represent fecal samples from control infants and red triangles represent fecal samples from infants who developed necrotizing enterocolitis.

In a comparison of DGGE profiles, there was no distinctive band associated with the development of NEC. There was a tendency for the simpler PCR-DGGE pattern for all the neonates at birth to become more diverse over time, but this was not a statistically significant trend. The increase in the bacterial complexity of the fecal samples during the first months after birth has previously been described, and these findings support the validity of our assays $(24,25)$. Furthermore, our data indicate that each neonate has a unique band pattern, and that this pattern does not resemble any other neonate's pattern during the time of the hospital stay as previously described (25). This could be because fecal samples were collected at distinct time points during the first 4 weeks of the neonate's life rather than over a long period of time (such as 2 years). In this cohort study, as reported by others $(24,26)$, DGGE profile analysis produced findings similar to those obtained from culture studies, confirming a lower biodiversity of bacteria in infants who go on to develop NEC.

It has been shown that there is a link between the presence of bacteria in amniotic fluid and the occurrence of preterm delivery. All the neonates included in this study were $<30$ weeks of gestation. However, bacteria frequently associated with preterm delivery, such as Mycoplasma hominis and Ureaplasma urealyticum (22), were not detected by culture techniques. Nevertheless, in the meconium, bacteria were detected both by culture and in the commensal PCR-DGGE.

Although we had a large population of premature neonates and a relatively large subpopulation who developed NEC, the statistical power of our study was nevertheless limited. Another difficulty was that each infant was found to host a particular pattern of fecal microflora (27), thereby defying simple statistical analysis. Finally, the interactions between abdominal symptoms, use of antibiotics, and fecal microflora are not likely to be simple. Some of the differences in fecal flora between cases with NEC and controls at 30 days of age may be a result of antibiotic treatment of NEC rather than part of the etiology. We did not attempt to disentangle these complexities because we predicted that the task would require a much larger study population.

We have recently shown, by in situ fluorescent hybridization laser capture microdissection and sequencing, a large variability in the bacteria in tissue specimens from neonates with NEC (28). Nevertheless, no potential pathogenic bacterial species, whether singly or in combination, was dominant in the samples, thereby serving to emphasize the complexity of the disease. 
To date, our study is the largest one involved in analyzing the fecal flora of premature neonates during the first month of life. By culturing the bacteria in fecal samples, we showed that premature neonates who develop NEC are colonized predominately by $\mathrm{G}^{+}$bacteria, in contrast to control neonates (who did not develop NEC), who were colonized by a significant diversity of microflora. Surprisingly, when we used molecular methods, we found no association between microflora profiles and subsequent development of NEC.

\section{METHODS}

\section{Patients and Sample Collection}

Between September 2006 and January 2009, preterm neonates of $<30$ weeks of gestation were recruited from a single level III neonatal intensive care unit at Rigshospitalet, Copenhagen, Denmark. All the patients underwent routine neonatal intensive care unit care as determined by the managing service. Only neonates with definite or advanced NEC, corresponding to Bell stage II or III (29), were included in the NEC group. The study was approved by the ethical committee for Copenhagen and Frederiksberg, Denmark (KF 01 287895), and informed consent was obtained from the parents of the neonates.

Fecal samples from the infants were collected by nurses of the department. The samples were collected from the neonates' diapers using sterile plastic spoons, and put in sterile plastic screw-cap tubes. The fecal samples were collected at the following time points: postnatal day 0-5 (sample 1), day 10 (sample 2), and day 30 (sample 3). The samples were stored at $4^{\circ} \mathrm{C}$ and processed as soon as possible. When the samples were received at the microbiological laboratory at Statens Serum Institute, they were immediately processed. The samples were prepared for culture, while the remaining fecal material was mixed with $1 \mathrm{ml}$ ox-broth and $10 \% \mathrm{vol} / \mathrm{vol}$ glycerol (SSI, Copenhagen, Denmark) and stored at $-80^{\circ} \mathrm{C}$ awaiting molecular analysis.

\section{Identification of Neonatal Fecal Bacterial Flora From Culture}

From each fecal sample, $200 \mathrm{mg}$ was transferred $1 \mathrm{ml}$ of sterile ultrapure water and mixed thoroughly. Samples were then plated on nonselective and selective media (SSI Diagnostica, Copenhagen, Denmark; see Table 4). Blood agar plates (5\% horse blood) and chocolate agar plates were used for general culture; blue agar plates (modified Drigalski) were used for the detection of $\mathrm{G}^{-}$bacteria, especially Enterobacteriaceae; and sabouraud agar plates were used for selective growth of yeast/fungi. The plates were incubated aerobically at $37^{\circ} \mathrm{C}$ for $24 \mathrm{~h}$. Cycloserine cefoxitin fructose agar plates were used as selective media for the detection of Clostridium difficile, incubated anaerobically $\left(5 \% \mathrm{CO}_{2}, 3 \% \mathrm{H}_{2}, 5 \% \mathrm{O}_{2}\right.$, and $87 \% \mathrm{~N}_{2}$ at $\left.37^{\circ} \mathrm{C}\right)$ for $48 \mathrm{~h}$. All anaerobic microorganisms were tested for the absence of growth under aerobic conditions (for 2 days), and antimicrobial susceptibility was tested by disk diffusion of $5 \mu \mathrm{g}$ metronidazole and $1 \mu \mathrm{g}$ kanamycin (Oxoid, Hampshire, UK). Subsequently, microbial identification was carried out on the basis of their growth on selective media, characteristics of colonies, and cellular morphology. All identifications of bacteria were confirmed biochemically using the automated identification system VITEK 2 (Bio Mérieux, Nürtingen, Germany). Isolates from the anaerobic plate were preserved at $-80^{\circ} \mathrm{C}$ for future identification. Quantification of bacterial load was not performed. The microorganisms were identified primarily at the species level.

\section{Extraction of Bacterial DNA From Fecal Samples}

Bacterial DNA extraction from fecal material is critical; essentially, it was carried out using a method developed in our laboratory (30). For DNA extraction, $200 \mathrm{mg}$ of the fecal sample was added to a $2 \mathrm{ml}$ vial containing $1.4 \mathrm{ml}$ of ASL buffer (stool lysis buffer; Qiagen, Hilden, Germany). To the sample, $0.3 \mathrm{~g}$ of zirconium beads (diameter, $0.1 \mathrm{~mm}$; Biospec Product, Bartlesville, OK) was added, and disrupted at $30 \mathrm{~Hz}$ for $6 \mathrm{~min}$ by a TissueLyser system (Qiagen). DNA was extracted using the QIAamp DNA stool Mini Kit (Qiagen) in accordance with the instructions of the manufacturer. DNA was eluted in a final volume of $100 \mu \mathrm{l}$ and stored at $-20^{\circ} \mathrm{C}$ until use.

\section{PCR Amplification of Bacterial DNA}

Aliquots $(10 \mu \mathrm{l})$ of purified DNA were applied to the following to give a $50 \mu \mathrm{l}$ PCR mixture: $4 \mu \mathrm{l}$ of sterilized water, $20 \mu \mathrm{l}$ of Eppendorf Mastermix (2.5×) (Eppendorf, Hamburg, Germany), and $8 \mu \mathrm{l}$ of each of the universal primers HDA1-GC and HDA2 (31). PCR was run in a Peltier Thermal Cycler (MJ Research). Initial preheating was at $96^{\circ} \mathrm{C}$ for $4 \mathrm{~min}$, followed by 30 cycles of denaturation at $96^{\circ} \mathrm{C}$ for $30 \mathrm{~s}$, annealing at $56^{\circ} \mathrm{C}$ for $30 \mathrm{~s}$, replication at $68^{\circ} \mathrm{C}$ for $1 \mathrm{~min}$, and termination at $68^{\circ} \mathrm{C}$ for $7 \mathrm{~min}$.

\section{Analysis of Fecal Microflora by DGGE}

DGGE was carried out using the procedure described by Muyzer et al. (32), using a DCode Universal Maturation Detection System instrument and gradient former model 475 in accordance with the manufacturer's instructions (Bio-Rad Labs, Hercules, CA). The denaturing gradient was formed with two $8 \%$ polyacrylamide gel (wt/vol, acrylamide/bisacrylamide, 37.5:1) stock solutions (Bio-Rad Labs) in $1 \times$ TAE ( $20 \mathrm{mmol} / \mathrm{l}$ Tris, $10 \mathrm{mmol} / \mathrm{l}$ acetate, $0.5 \mathrm{EDTA}, \mathrm{pH}$ 7.4). The gels were made with denaturing gradient solution ranging from 30 to $65 \%$. The $100 \%$ denaturant solution contained deionized formamide and $7 \mathrm{~mol} / \mathrm{l}$ of urea. Before loading, $20 \mu \mathrm{l}$ of the PCR product was mixed

Table 4. Culture media used for microbiological analysis

\begin{tabular}{|c|c|c|c|c|}
\hline \multirow[b]{2}{*}{ Culture medium } & \multicolumn{3}{|c|}{ Incubation } & \multirow[b]{2}{*}{ Bacterial species } \\
\hline & Time & Temperature & Atmosphere & \\
\hline \multicolumn{5}{|l|}{ Anaerobic incubation } \\
\hline Chocolate agar & 24 and 48 hours & $37^{\circ} \mathrm{C}$ & Aerobic & Aerobe G+/G- species \\
\hline Blue (Drigalski) agar & 24 and 48 hours & $37^{\circ} \mathrm{C}$ & Aerobic & Enterobacteriacea \\
\hline \multicolumn{5}{|l|}{ Anaerobic incubation } \\
\hline CCFA & 48 hours & $37^{\circ} \mathrm{C}$ & $\begin{array}{l}\text { Anaerobic jars } 5 \% \mathrm{CO}_{2^{\prime}} 3 \% \mathrm{H}_{2^{\prime}} \\
5 \% \mathrm{O}_{2^{\prime}} \text { and } 87 \% \mathrm{~N}_{2}\end{array}$ & Clostridium spp. \\
\hline Anaerobic plate & 5-6 days & $37^{\circ} \mathrm{C}$ & Anaerobic jars & Anaerobe G+/G-species \\
\hline
\end{tabular}

All media were obtained from Statens Serum Institut (SSI Diagnostica).

CCFA, cycloserine cefoxitin fructose agar. 
with $3 \mu \mathrm{l}$ of $6 \times$ loading dye solution. Gels were run in $1 \times$ TAE at $60^{\circ} \mathrm{C}$ for $16 \mathrm{~h}$ at $70 \mathrm{~V}$, stained with GelRed (Biotium, Harvard, CA) for $35 \mathrm{~min}$, and viewed by UV transillumination. The BioNumerics software, version 6.01 (Applied Maths, Sint-Martens-Latem, Belgium) was used for identification of bands and normalization of band patterns from DGGE gels.

\section{Statistics}

Statistical analyses were performed using SAS version 9.1.3 for Windows (SAS Institute, Cary, NC). A one-way analysis of variance by Fisher was used to evaluate the results obtained from culture. Bacteria were categorized as $\mathrm{G}^{+}$and $\mathrm{G}^{-}$bacteria. All factors that showed a statistically significant correlation with simple linear regression were analyzed together in a stepwise linear regression. The factors selected for analysis as being possibly explanatory were gender, gestational age, birth weight, type of enteral feed (own mother's milk, donated breast milk, formula), parenteral nutrition, and antibiotics administered.

Molecular data obtained by DGGE were represented as 0 (indicating the absence of a band) or 1 (indicating the presence of a band) and autoscaled (centered and scaled to unit variance for each variable) for PCA; the resultant PCA scores were plotted two-dimensionally. The PCA models were developed in LatentiX version 2.00 (Latent5, Copenhagen, Denmark).

\section{ACKNOWLEDGMENTS}

The authors thank all the clinical staff at the Neonatal Department, Rigshospitalet, Copenhagen, Denmark, for their help with obtaining the samples, and Berit Jensen for her valuable technical assistance with laboratory analyses. We would like to pay our respects to our late colleague S. Bodé, Neonatal Department, Rigshospitalet, Copenhagen, who was a driving force during this study.

\section{REFERENCES}

1. Lin PW, Stoll BJ. Necrotising enterocolitis. Lancet 2006;368:1271-83.

2. Blakely ML, Lally KP, McDonald S, et al.; NEC Subcommittee of the NICHD Neonatal Research Network. Postoperative outcomes of extremely low birth-weight infants with necrotizing enterocolitis or isolated intestinal perforation: a prospective cohort study by the NICHD Neonatal Research Network. Ann Surg 2005;241:984-9; discussion 989-94.

3. McCracken VJ, Lorenz RG. The gastrointestinal ecosystem: a precarious alliance among epithelium, immunity and microbiota. Cell Microbiol 2001;3:1-11.

4. Lin PW, Nasr TR, Stoll BJ. Necrotizing enterocolitis: recent scientific advances in pathophysiology and prevention. Semin Perinatol 2008;32:70-82.

5. Neu J. Neonatal necrotizing enterocolitis: an update. Acta Paediatr Suppl 2005;94:100-5.

6. Schnabl KL, Van Aerde JE, Thomson AB, Clandinin MT. Necrotizing enterocolitis: a multifactorial disease with no cure. World J Gastroenterol 2008;14:2142-61.

7. Updegrove K. Necrotizing enterocolitis: the evidence for use of human milk in prevention and treatment. J Hum Lact 2004;20:335-9.

8. Peter CS, Feuerhahn M, Bohnhorst B, et al. Necrotising enterocolitis: is there a relationship to specific pathogens? Eur J Pediatr 1999;158: $67-70$.

9. Westerbeek EA, van den Berg A, Lafeber HN, Knol J, Fetter WP, van Elburg $\mathrm{RM}$. The intestinal bacterial colonisation in preterm infants: a review of the literature. Clin Nutr 2006;25:361-8.

10. Palmer C, Bik EM, DiGiulio DB, Relman DA, Brown PO. Development of the human infant intestinal microbiota. PLoS Biol 2007;5:e177.

11.. Blakey JL, Lubitz L, Campbell NT, Gillam GL, Bishop RF, Barnes GL. Enteric colonization in sporadic neonatal necrotizing enterocolitis. J Pediatr Gastroenterol Nutr 1985;4:591-5.
12 Gewolb IH, Schwalbe RS, Taciak VL, Harrison TS, Panigrahi P. Stool microflora in extremely low birthweight infants. Arch Dis Child Fetal Neonatal Ed 1999;80:F167-73.

13. Rotimi VO, Olowe SA, Ahmed I. The development of bacterial flora of premature neonates. J Hyg (Lond) 1985;94:309-18.

14. Stark PL, Lee A. The microbial ecology of the large bowel of breast-fed and formula-fed infants during the first year of life. J Med Microbiol 1982;15:189-203.

15. Björkstén B. The intrauterine and postnatal environments. J Allergy Clin Immunol 1999;104:1119-27.

16. Dittmar E, Beyer P, Fischer D, et al. Necrotizing enterocolitis of the neonate with Clostridium perfringens: diagnosis, clinical course, and role of alpha toxin. Eur J Pediatr 2008;167:891-5.

17. Duffy LC, Zielezny MA, Carrion V, et al. Concordance of bacterial cultures with endotoxin and interleukin-6 in necrotizing enterocolitis. Dig Dis Sci 1997;42:359-65.

18. Hällström M, Eerola E, Vuento R, Janas M, Tammela O. Effects of mode of delivery and necrotising enterocolitis on the intestinal microflora in preterm infants. Eur J Clin Microbiol Infect Dis 2004;23:463-70.

19. Kosloske AM, Ulrich JA. A bacteriologic basis for the clinical presentations of necrotizing enterocolitis. J Pediatr Surg 1980;15:558-64.

20. Mshvildadze M, Neu J, Shuster J, Theriaque D, Li N, Mai V. Intestinal microbial ecology in premature infants assessed with non-culture-based techniques. J Pediatr 2010;156:20-5.

21. Hoy CM, Wood CM, Hawkey PM, Puntis JW. Duodenal microflora in very-low-birth-weight neonates and relation to necrotizing enterocolitis. J Clin Microbiol 2000;38:4539-47.

22. Millar MR, Linton CJ, Cade A, Glancy D, Hall M, Jalal H. Application of $16 \mathrm{~S}$ rRNA gene PCR to study bowel flora of preterm infants with and without necrotizing enterocolitis. J Clin Microbiol 1996;34:2506-10.

23. de la Cochetiere MF, Piloquet H, des Robert C, Darmaun D, Galmiche JP, Roze JC. Early intestinal bacterial colonization and necrotizing enterocolitis in premature infants: the putative role of Clostridium. Pediatr Res 2004;56:366-70.

24. Favier CF, Vaughan EE, De Vos WM, Akkermans AD. Molecular monitoring of succession of bacterial communities in human neonates. Appl Environ Microbiol 2002;68:219-26.

25. Schwiertz A, Gruhl B, Löbnitz M, Michel P, Radke M, Blaut M. Development of the intestinal bacterial composition in hospitalized preterm infants in comparison with breast-fed, full-term infants. Pediatr Res 2003;54:393-9.

26. Rougé C, Goldenberg O, Ferraris L, et al. Investigation of the intestinal microbiota in preterm infants using different methods. Anaerobe 2010;16:362-70.

27. Zoetendal EG, Akkermans AD, De Vos WM. Temperature gradient gel electrophoresis analysis of $16 \mathrm{~S}$ rRNA from human fecal samples reveals stable and host-specific communities of active bacteria. Appl Environ Microbiol 1998;64:3854-9.

28. Smith B, Bodé S, Petersen BL, et al. Community analysis of bacteria colonizing intestinal tissue of neonates with necrotizing enterocolitis. BMC Microbiol 2011;11:73.

29. Bell MJ, Ternberg JL, Feigin RD, et al. Neonatal necrotizing enterocolitis. Therapeutic decisions based upon clinical staging. Ann Surg 1978;187:1-7.

30. Smith B, Li N, Andersen AS, Slotved HC, Krogfelt KA. Optimising bacterial DNA extraction from faecal samples: comparison of three methods. Open Microbiol J 2011;5:14-7.

31. Walter J, Tannock GW, Tilsala-Timisjarvi A, et al. Detection and identification of gastrointestinal Lactobacillus species by using denaturing gradient gel electrophoresis and species-specific PCR primers. Appl Environ Microbiol 2000;66:297-303.

32. Muyzer G, de Waal EC, Uitterlinden AG. Profiling of complex microbial populations by denaturing gradient gel electrophoresis analysis of polymerase chain reaction-amplified genes coding for $16 \mathrm{~S}$ rRNA. Appl Environ Microbiol 1993;59:695-700. 